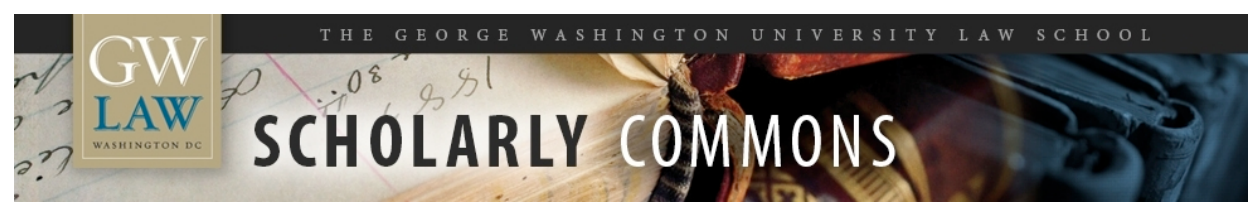

\title{
The Admissibility of Forensic Reports in the Post-Justice Scalia Supreme Court
}

\author{
Laird Kirkpatrick \\ George Washington University Law School, Ikirkpatrick@law.gwu.edu
}

Follow this and additional works at: https://scholarship.law.gwu.edu/faculty_publications

Part of the Law Commons

\section{Recommended Citation}

Kirkpatrick, Laird C., The Admissibility of Forensic Reports in the Post-Justice Scalia Supreme Court (2019). GWU Law School Public Law Research Paper No. 2019-40; GWU Legal Studies Research Paper No. 2019-40. Available at SSRN: https://ssrn.com/abstract=3429152

This Article is brought to you for free and open access by the Faculty Scholarship at Scholarly Commons. It has been accepted for inclusion in GW Law Faculty Publications \& Other Works by an authorized administrator of Scholarly Commons. For more information, please contact spagel@law.gwu.edu. 


\section{The Admissibility of Forensic Reports in the Post-Justice Scalia Supreme Court}

Forensic reports linking a defendant to a crime, such as drug tests, blood analysis, DNA profiles and much more, often constitute the most powerful and persuasive evidence that can be offered at a criminal trial. Yet the Supreme Court is sharply divided about the constitutionally required foundation for the admission of such reports. Its opinions on the question "have sown confusion in courts across the country," as recently noted by Justice Gorsuch in a dissent to a denial of a Writ of Certiorari. ${ }^{1}$ Justice Gorsuch acknowledged that "the problem appears to be largely of our creation." ${ }^{2}$ In Melendez-Diaz v. Massachusetts, ${ }^{3}$ an opinion by Justice Scalia, a narrow 5-4 majority held that the analyst who prepared a drug analysis report must be produced. But in Williams v. Illinois, ${ }^{4}$ the plurality opinion held that an Illinois analyst could refer to the content and apparent accuracy of an out-of-court report prepared by an analyst in Maryland (who did not testify) without violating the Confrontation Clause. And the concurring opinion of Justice Thomas, which controlled the outcome in Williams, held that the Confrontation Clause did not even apply if the forensic report was not certified. Thus the prevailing confusion in the lower courts is understandable. In his extremely important dissenting opinion, Justice Gorsuch went on to reveal much of his own thinking about the application of the Sixth Amendment to forensic reports. His views, which are analyzed in this article, are likely to play a key role in shaping the future direction of confrontation jurisprudence and determining whether Justice Scalia's legacy of forceful support for the Sixth Amendment right of confrontation will survive his departure from the Court.

The view that only "testimonial" hearsay is within the scope of the Confrontation Clause was first announced by Justice Scalia in the cases of Crawford $v$. Washington ${ }^{5}$ and Davis v. Washington. ${ }^{6}$ Crawford rejected the two-pronged test of Ohio v. Roberts ${ }^{7}$ based on "reliability" and "unavailability" which governed the jurisprudence in this area for the previous 25 years.

In Crawford, Justice Scalia wrote for the majority that if the hearsay was testimonial it was not admissible against a criminal defendant, unless the declarant was subject to cross-examination either prior to trial or at the time the statement was offered. Justice Scalia did not attempt to provide a settled definition of "testimonial," but he noted that one possible definition is "statements that were made under circumstances which would lead an objective witness reasonably to believe that the statement would be available for use at a later trial." 8

In Melendez-Diaz the court addressed the constitutionality of a Massachusetts statute allowing a forensic report to be introduced without calling the analyst who prepared it. ${ }^{9}$ The case involved a certificate by an analyst at the state crime lab that the substance seized from defendant was cocaine of

\footnotetext{
${ }^{1}$ Stuart v. Alabama, 139 S .Ct. 36 (2018) (Gorsuch, J. dissenting from denial of certiorari).

${ }^{2}$ Id.

${ }^{3}$ Melendez-Diaz v. Massachusetts, 557 U.S. 305 (2009).

${ }^{4}$ Williams v. Illinois, 567 U.S. 50 (2012).

${ }^{5}$ Crawford v. Washington, 541 U.S. 36 (2004).

${ }^{6}$ Davis v. Washington, 547 U.S. 813 (2006).

${ }^{7}$ Ohio v. Roberts, 448 U.S. 56 (1980).

8541 U.S. at 52.

${ }^{9}$ See Mass. Gen. Laws, ch. 111, §13 (2009).
} 
a certainty quantity. Justice Scalia, joined by Justices Stevens, Souter, Thomas, and Ginsburg, held that there was "little doubt" that the certified forensic reports fell within the "core class of testimonial statements" because they were "functionally identical" to in-court testimony. Not only would the circumstances lead an objective witness to reasonably believe they would be used at trial, that was their "sole purpose" under Massachusetts law. ${ }^{10}$

Justice Kennedy filed a dissent, joined by Justices Alito, Breyer and Roberts, arguing that there was no need to produce an analyst who prepared a forensic report because they were not "accusatory witnesses" or "conventional" witnesses. ${ }^{11}$ Moreover, because many analysts may be involved in preparing forensic reports it would be unclear who would need to testify. The dissent also expressed concern about the logistical difficulties that states would encounter in complying with the requirement. The dissent noted that the defendant had the right to subpoena the analyst if he wished to challenge the report. Justice Scalia rejected all of these arguments, saying that the Sixth Amendment drew no such distinctions between the types of "witnesses" and that the Confrontation Clause placed the burden of calling the analyst on the State, not the defendant. He also noted that there has been extensive documentation of "serious deficiencies ... in the forensic evidence used in criminal trials," thereby justifying the need for testing of such reports by cross-examination. ${ }^{12}$

The most recent decision concerning the application of the Confrontation Clause to forensic reports is Williams $v$. Illinois, ${ }^{13}$ a rape prosecution. A vaginal swab from the victim had been sent by the state of Illinois to Cellmark, a private DNA testing service located in Maryland. Cellmark examined semen found on the swab and prepared a DNA profile. When the DNA profile was sent back to Illinois, it was run through the Illinois DNA database where it was found to match the DNA profile of Williams (his DNA had been collected based upon an earlier unrelated conviction). At trial an analyst from the Illinois crime lab testified that the Cellmark profile "matched" the profile of Williams in the Illinois database. However, no one from Cellmark was called to testify that the DNA profile was indeed made from the semen on the vaginal swab sent by the State of Illinois or that the DNA analysis had been conducted properly. The Cellmark report itself was not offered into evidence. The state relied instead on the testimony of the Illinois analyst that there was a match between Williams's DNA profile and the DNA profile made from "the semen from the vaginal swabs of the [victim]." Williams argued this was a Confrontation Clause violation, because the Cellmark DNA profile was being offered for its truth, i.e., that it had been prepared properly and was accurately derived from the semen on the vaginal swab sent by the state of Illinois. The testimony of the analyst was in effect bringing the out-of-court report into evidence.

The Supreme Court split sharply in deciding the case. A four-person plurality opinion, written by Justice Alito and joined by Justices Kennedy, Roberts and Breyer, held that the Cellmark report was not being offered for its truth and was therefore not "testimonial." As an alternate ground for affirmance, the plurality relied on the fact that the report was not prepared for the primary purpose of "accusing" a "known suspect" or a "targeted" individual. A dissent written by Justice Kagan, and joined by Justices Sotomayor, Ginsburg and Scalia, found a confrontation violation on the ground that the Cellmark report was being offered for its truth and was testimonial. The dissent noted that Williams's attorney could

\footnotetext{
10557 U.S. at 310-11.

${ }^{11}$ Id. at 330 (Kennedy, J., dissenting).

12 Id. at 318-22.

${ }^{13}$ Williams v. Illinois, 567 U.S. 50 (2012).
} 
not ask questions about the Cellmark analyst's "proficiency, the care he took in performing his work, or his veracity." He could not probe whether "the analyst had tested the wrong vial, inverted the labels on the sample, committed some more technical error, or simply made up the results." 14

Justice Thomas concurred with the decision to affirm, but strongly rejected all the grounds of the plurality opinion. ${ }^{15} \mathrm{He}$ agreed with the dissent that the Cellmark report was being offered for its truth and also rejected the alternate ground of the plurality opinion. However, he found the Cellmark report was not "testimonial" because it lacked sufficient "formality" - the report was prepared by a private laboratory and was not certified. Based on this 4-4-1 split, the decision was affirmed.

An example of the confusion created by Williams is Stuart $v$ Alabama,${ }^{16}$ a case in which the Supreme Court recently denied a petition for writ of certiorari. Stuart was prosecuted for driving under the influence. To prove its case the State introduced the results of a blood-alcohol test conducted hours after her arrest, but failed to produce the analyst who conducted the test. Instead the State called a different analyst who used the results of the test and the rate at which alcohol is metabolized to give an estimate for the jury of Stuart's alcohol level hours earlier when she was driving. The State argued that there was no confrontation violation because the report was not being offered for the truth of what it said about Stuart's blood-alcohol at the time of the test, only to provide a basis for the State's expert to estimate Stuart's blood-alcohol level when she was driving. Stuart was convicted and her conviction was affirmed by the Alabama Court of Criminal Appeals. Justice Gorsuch, joined by Justice Sotomayor, dissented from the Court's denial of her Writ of Certiorari and expressed his strong view that Stuart's confrontation right was denied.

First, Justice Gorsuch observed that "forensic evidence plays a decisive role in criminal trials today" and noted that it is not "immune from the risk of manipulation." ${ }^{17}$ He further stated that "to guard against such mischief and mistake and the risk of false convictions they invite, our criminal justice system depends on adversarial testing and cross-examination. ${ }^{18}$ Thus it appears that he would vote to reaffirm the holding of Melendez-Diaz.

Second, Justice Gorsuch emphatically rejected the argument made by the State of Alabama in the Stuart case that the earlier report measuring Stuart's blood alcohol was not being offered for its truth. He said "After all, why would any prosecutor bother to offer in evidence the nontestifying analyst's report in this case except to prove the truth of its assertions about the level of alcohol in Ms. Stuart's blood at the time of the test? The whole point of the exercise was to establish-because of the report's truth-a basis for the jury to credit the testifying expert's estimation of Ms. Stuart's blood-alcohol level hours earlier." ${ }^{19} \mathrm{His}$ analysis indicates that he would reject the plurality's conclusion in Williams that an out-ofcourt DNA profile was not being offered for its truth when it was claimed by a testifying analyst to be a "match" with Williams's DNA.

\footnotetext{
${ }^{14} / d$. at 124-125 (Kagan, J., dissenting).

${ }^{15} / d$. at 103 (Thomas, J. concurring).

${ }^{16}$ Stuart v. Alabama, 139 S. Ct. 36 (2018) (Gorsuch, J. dissenting from denial of certiorari).

${ }^{17}$ Id. (quoting Melendez-Diaz, 557 U.S. at 318)

${ }^{18} \mathrm{Id}$.

${ }^{19} / d$. at 37.
} 
Third, he rejects Justice Thomas's view that the Confrontation Clause applies only to certified documents, because there was no indication in Stuart that the report had been certified. Justice Thomas's view, which was the basis of his concurrence in Williams, was rejected by the other eight justices. As Justice Kagan said in her dissent, applying the Confrontation Clause only to a certified forensic report would allow the prosecution easily to avoid the demands of the Confrontation Clause "by using the right kind of forms with right kind of language ... principally, never call anything a "certificate." 20

It is possible that Justice Gorsuch could support the result in Williams by accepting the alternate ground of the plurality opinion, which was that a forensic report qualifies as testimonial only when it is "prepared for the primary purpose of accusing a targeted individual" who is "in custody [or] under suspicion." ${ }^{21}$ In Williams the Cellmark DNA analysis was performed at a time when there was no known suspect, whereas in Stuart the defendant was already under arrest for driving under the influence. In his dissent in Stuart, Justice Gorsuch took notice of this alternate ground but did not take a position on it. ${ }^{22}$ Nonetheless it seems unlikely he would endorse it for several reasons.

First, the Court itself has never previously held or even suggested that the Confrontation Clause applies only to "accusatory" statements made against "targeted" individuals. As Justice Kagan stated in her dissent "[w]here that test comes from is anybody's guess." ${ }^{23}$ In his concurring opinion, Justice Thomas commented that a requirement that the statement must be made against a targeted individual "lacks any grounding in constitutional text, in history, or in logic." ${ }^{24}$ He noted that ex parte examinations of witnesses in $16^{\text {th }}$ century England often occurred "before the accused's identity was known." 25 With respect to the suggestion that the statement must be "accusatory," he commented that "a statement that is not facially inculpatory may turn out to be highly probative of a defendant's guilt when considered with other evidence." 26

Second, confining the Confrontation Clause to cases where there are "known suspects" addresses only one of concerns about forensic reports - a possible motive to fabricate by the analyst. But as Justice Kagan said in her dissent: "[S]urely the typical problem with laboratory analyses-and the typical focus of cross-examination-has to do with careless or incompetent work, rather than with personal vendettas. And as to that predominant concern, it makes not a whit of difference whether, at the time of the laboratory test, the police already have a suspect." ${ }^{27}$ Justice Gorsuch appears to agree. In his dissent in Stuart, he indicated his awareness that cross-examination is needed to address more than motivational concerns about the analyst. He said "[e]ven the most well-meaning analyst may lack essential training, contaminate a sample, or err during the testing process," and that "to guard against such mischief and mistake and the risk of false convictions they invite, our criminal justice system depends on adversarial testing and cross-examination." 28

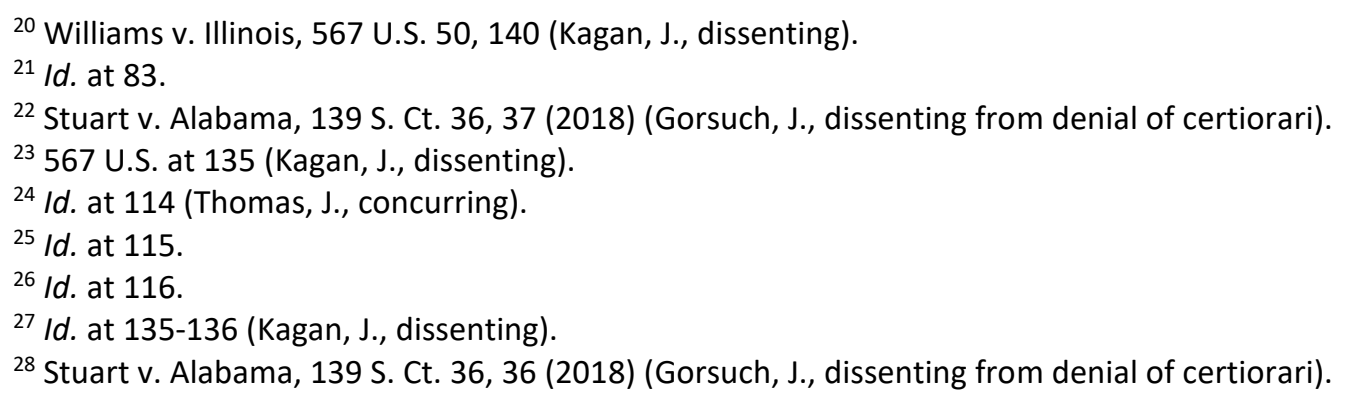


Finally, this exceedingly constricted interpretation of the confrontation right is being advocated by the same Justices who opposed the holding of Melendez-Diaz, and Justice Gorsuch has indicated he supports that decision. Moreover, there is no indication that the Justices who joined the plurality opinion would limit the "targeted" individual requirement to forensic reports, because the opinion suggests that having an identified suspect was a partial basis of decision in cases such as Crawford and Hammon v. Indiana ${ }^{29}$ that did not involve a forensic report. Both of these cases involved hearsay statements by a wife incriminating her husband for assaultive behavior. However, there is no indication in either of those decisions that the confrontation violation would have been eliminated if the declarants had directed their incriminating statements against a stranger rather than against a known suspect, and that would be an absurd outcome as a matter of policy.

If the "targeted" individual requirement were extended beyond forensic reports to other types of hearsay statements it would amount to one of the most extreme retrenchments of confrontation protections ever proposed. Often the most damaging and untrustworthy hearsay statements are made prior to the time the defendant becomes a suspect. Statements made that cause someone to become a suspect can often be more incriminating than statements made after they have been arrested. Eye witness descriptions of the alleged perpetrator, his clothing, the car he was driving, the manner in which the crime was committed, and other circumstances are usually obtained before a suspect is identified or apprehended. Participants in a crime often attempt to implicate others and turn them into suspects in order to obtain leniency for themselves. The dangers of wrongful conviction would rise exponentially if hearsay statements given prior to the identification of a suspect could be introduced at a criminal trial without any constitutional requirement that the declarant be confronted and cross examined. For these reasons, it seems highly doubtful that Justice Gorsuch would join the alternate ground of the plurality opinion in Williams.

Apart from Melendez-Diaz and Williams, there is one other case involving forensic reports that has sharply divided the Court-Bullcoming v. New Mexico. ${ }^{30}$ It addressed the question of who must be called by the government to be cross examined about the report. Bullcoming was charged for driving while intoxicated, and the State offered a blood test report indicating a blood-alcohol level well above the legal threshold. The analyst who took and analyzed the samples did not appear at trial, and the record showed only that he had been placed on unpaid leave for undisclosed reasons. The prosecutor instead called another analyst from the same lab to answer questions about the process of conducting such alcohol tests, but the analyst was not involved in conducting defendant's test. The court, again in a 5-4 decision, held that the presence of the second analyst was not sufficient to satisfy the Confrontation Clause because such "surrogate testimony" could not convey what the analyst who actually conducted the test "knew or observed about the events his certification concerned." ${ }^{31}$ Moreover, such surrogate testimony would not expose "any lapses or lies on the certifying analyst's part." ${ }^{32}$ Therefore, admission of the report violated defendant's confrontation rights.

Interestingly, Justice Gorsuch's dissent in Stuart also reveals his views about this issue, even though he did not comment on it directly. At Stuart's trial, the State had called a Dr. Hudson, who was the section

\footnotetext{
${ }^{29}$ Davis v. Washington, 547 U.S. 813 (2006).

${ }^{30}$ Bullcoming v. New Mexico, 564 U.S.647 (2011)

${ }^{31}$ Id. at 661.

32 Id. at 662.
} 
chief of the toxicology laboratory, rather than calling the analyst who prepared the blood-alcohol test. ${ }^{33}$ Dr. Hudson testified about the policies and procedures of the toxicology laboratory, including "controls in the analysis and laboratory's standard practice of having the results of the analysis independently reviewed." ${ }^{34}$ He stated that he was "responsible for the day-to-day workflow in the laboratory, testing assignments for cases, as well as personnel management." ${ }^{35}$ The Alabama Court concluded that "t]his testimony provided [Stuart] with ample opportunity to cross examine [Dr. Hudson] regarding the [blood]-analysis report." ${ }^{36}$ However, there was no indication that Dr. Hudson had any personal knowledge or involvement with the report relating to Stuart. Presumably for this reason, Justice Gorsuch clearly rejected this holding of the Alabama court and instead concluded that " $t$ ] he engine of cross-examination was left unengaged, and the Sixth Amendment was violated." 37

Based on the analysis above, it appears that Justice Gorsuch would support the result in Melendez-Diaz and Bullcoming and agree with the dissent in Williams, just as Justice Scalia did. It remains to be seen what position Justice Kavanaugh will take on these questions. But even if Justice Kavanaugh follows the voting pattern of Justice Kennedy, the justice he replaced, it would not change the outcome of these cases, unless one of the other Justices has a change of heart or a new Justice is appointed.

Perhaps the greatest significance of Justice Gorsuch's dissent in Stuart is his statement that "[W]e owe lower courts struggling to abide our holdings more clarity than we have afforded them in this area." ${ }^{38}$ He clearly is urging his colleagues to revisit Williams, and he apparently intends to do what he can to clarify the law governing the admissibility of forensic reports. In doing so, he will be entering a fierce ideological battlefield. Some of his colleagues appear ready to dismantle the Crawford framework itself that was built under the leadership of Justice Scalia. In Justice Kennedy's dissent in Bullcoming, joined by Justices Alito, Roberts, and Breyer, he stated ominously that "it bears remembering that the Crawford approach was not preordained." ${ }^{39}$ He declared that "[t]his Court's missteps have produced an interpretation of the word 'witness' at odds with its meaning elsewhere in the Constitution, including elsewhere in the Sixth Amendment, and at odds with the sound administration of justice." ${ }^{40} \mathrm{He}$ stated that "[i]t is time to return to solid ground." ${ }^{11}$ In Williams, the same four Justices sought to constrict the scope of Crawford by interpreting "testimonial" so narrowly that it would leave major areas of hearsay untouched by limiting it to "accusatory" statements made against a targeted individual or "known suspect." ${ }^{42}$ This effort by Justice Alito, who wrote the plurality opinion, to so drastically narrow the Confrontation Clause prompted Justice Kagan to say acidly in her dissent that “I call Justice Alito's opinion 'the plurality,' because that is the conventional term for it. But in all except its disposition, his

\footnotetext{
33 (unpublished opinion at 8(a)) ApPendix to Petition for Writ Of Certiorari, Stuart v. Alabama, 139 S. Ct. 36 (2018) (No. 17-1676) (providing the unpublished opinion of the Ala. Ct. of Crim. App.), available at https://www.supremecourt.gov/DocketPDF/17/17- 
opinion is a dissent: Five Justices specifically reject every aspect of its reasoning and every paragraph of its explication." 43

As Justice Gorsuch enters this battlefield, it might be useful for him to remind his colleagues of the view of confrontation rights conveyed by the Court's promulgation of the Federal Rules of Evidence under its rule making power in 1973 . The rule dealing with public records was specifically drafted to avoid a collision with the Confrontation Clause. As approved and submitted by the Supreme Court and ultimately adopted by Congress, FRE 803(8) creates a hearsay exception for "a record or statement of a public office if it sets out in a civil case or against the government in a criminal case, factual findings from a legally authorized investigation." The clear negative implication of this exception is that "factual findings from a legally authorized investigation" are not admissible against a criminal defendant. The Advisory Committee's Note accompanying the proposed rule, and submitted to Congress as explanatory text, made this clear by stating that such reports "are admissible only in civil cases and against the government in criminal cases in view of the almost certain collision with confrontation rights which would result from their use against the accused in a criminal case." ${ }^{44}$ (emphasis added) This view expressed in the Advisory Committee's Note to the Court's own rule supports the majority position in both Melendez-Diaz and Bullcoming and the dissent's view in Williams. ${ }^{45}$

Justice Gorsuch and Justice Sotomayor are to be applauded for their effort to have the Court address the chaos left by the Williams decision. It is unclear what support they will receive from the other members of the Court. Justice Kavanaugh is the successor to Justice Kennedy and his former law clerk, and Justice Kennedy was the primary ideological adversary of Justice Scalia on the admissibility of forensic reports. At the same time, Justice Kavanaugh is generally viewed as an "originalist" in the Justice Scalia tradition. ${ }^{46}$ The Crawford opinion is not only a paradigm example of Justice Scalia's originalism, but according to one source he described it as his favorite case. ${ }^{47}$ Justice Thomas is certain to adhere to his position that formality is the decisive factor defining the scope of confrontation rights, because he has asserted that view in confrontation cases even preceding Crawford. ${ }^{48}$ On the other hand, Justice Breyer seems open to new approaches. He requested reargument in Williams, and indicated his dissatisfaction with both the plurality and dissenting opinions. ${ }^{49}$ His concern about the administrative burden on states of producing an analyst may be mitigated somewhat by evidence of successful adaptation by states to this requirement in the years since Melendez-Diaz. But he clearly

\footnotetext{
${ }^{43}$ Id. at 120 (Kagan, J., dissenting).

${ }^{44}$ Advisory Committee's Note, Fed. R. Evid. 803(8)(A)(iii).

${ }^{45}$ Forensic reports can be admitted under certain other exceptions, particularly FRE 803(5), the exception for past recollection recorded, because if the analyst testifies the confrontation concern is eliminated. Lower courts have also recognized a "ministerial" exception to FRE 803(8) allowing routine, nonadversarial reports, such as one related to the calibration of a testing device, to be admitted. See generally Christopher B. Mueller \& Laird C. Kirkpatrick, 4 Federal Evidence 8:91 (4 ${ }^{\text {th }}$ ed. 2013)

46 "For both liberals and conservatives, a central fact about judge Brett Kavanaugh is that he is an 'originalist." https://www.politico.com/magazine/story/2018/08/09/kanavaugh-originalist-why-you-shouldnt-care-219344. 47 Jeffrey Toobin, The Nine: Inside the Secret World of the Supreme Court 317 (2007) ("Asked at a public forum his favorite of his opinions-a common question for justices in such settings-he came up with an esoteric case interpreting the Confrontation Clause of the Sixth Amendment"; presumably that case was Crawford).

${ }^{48}$ See White v. Illinois, 502 U.S. 346, 365 (1992) (Thomas, J., concurring)

${ }^{49}$ Williams v. Illinois, 567 U.S. 50, 86 (2012) (Breyer, J., concurring) ("neither the plurality nor the dissent answers adequately" the question presented).
} 
seeks greater consensus from his colleagues about who it is that the government must produce to be cross-examined and whether any single witness will be adequate. ${ }^{50}$

The unfortunate impact of the Williams decision is that it leaves the state of the law in cases involving similar facts controlled by Justice Thomas's concurring opinion, which extends confrontation rights only to forensic reports that are sworn or certified--a requirement which the eight other Justices reject. This requirement was disputed by the historical analysis in Crawford, where the Court stated: "We find it implausible that a provision which concededly condemned trial by sworn ex parte affidavit thought trial by unsworn ex parte affidavit perfectly $\mathrm{OK} .{ }^{\prime 51}$ As the dissent points out, the certification requirement makes the right to confrontation "easily erasable" and "turn[s] the Confrontation Clause upside down" by making presumably less reliable uncertified reports exempt from confrontation, thereby diminishing a defendant's rights "in the very cases in which the accused should 'enjoy the right to be confronted with the witnesses against him."' 52 Hopefully Justice Gorsuch will be successful in persuading his colleagues to provide more coherent guidance to lower courts about when an analyst from the forensic laboratory must be produced for cross-examination and who that representative should be.

${ }^{50} / d$. at 90 . Justice Breyer's reluctance to require anyone from a crime lab to testify in support of a forensic report is somewhat surprising, since he is from Massachusetts where there have been some of the most sensational and widely-publicized crime lab scandals resulting in dismissal of thousands of convictions. See https://www.washingtonpost.com/news/true-crime/wp/2017/12/28/massachusetts-prosecutors-to-throw-out8000-convictions-in-second-drug-lab-scandal/?utm term=.ce828668bd7b

${ }^{51}$ Crawford v. Washington, 541 U.S. 36, 52-53, n. 3 (2004).

52 Williams v. Illinois, 567 U.S. 50, 140 (2012) (Kagan, J. dissenting). As Justice Kagan said in frustration elsewhere in her dissent, "what a way to run a criminal justice system." Id. at 133. 